\title{
Diagnosis and surgical treatment of a chronic Staphylococcus aureus infection (botryomycosis) as a long-term complication after castration - a case report
}

\author{
Philipp Conze', Andreas Beineke'2, Andreas Mietze ${ }^{3}$ and Florian Geburek ${ }^{1}$ \\ ${ }^{1}$ Clinic for Horses, University of Veterinary Medicine Hannover, Foundation \\ 2 Department of Pathology, University of Veterinary Medicine Hannover, Foundation \\ ${ }^{3}$ Institute for Microbiology, University of Veterinary Medicine Hannover, Foundation
}

Summary: An eight-year-old grey Mecklenburger warmblood gelding was presented for clinical examination with a history of preputial swelling and oedema. Castration was completed at least five years ago. The skin was intact and a firm, diffuse swelling was found in the left inguinal region at the caudal part of the prepuce. Transcutaneous ultrasonography revealed an oedematous subcutis and a spherical, moderately demarcated mass with an echoic capsule and a hypoechoic centre, extending into the left external inguinal ring. After surgical removal, histopathologic and bacteriologic evaluation led to the diagnosis of chronic Staphylococcus aureus infection (botryomycosis). This case report describes the diagnosis, surgical and antimicrobial treatment and successful outcome of this nowadays seldom reported longterm complication after castration.

Keywords: horse / castration / complication / spermatic cord / granuloma / Staphylococcus aureus / botryomycosis

Diagnose und chirurgische Therapie einer chronischen Staphylococcus aureus Infektion (Botryomykose) als Langzeitkomplikation nach Kastration - ein Fallbericht

Ein acht Jahre alter Mecklenburger Schimmel-Wallach wurde aufgrund einer diffusen, ödematösen Schwellung im Bereich des Präputiums an der Klinik für Pferde der Stiftung Tierärztliche Hochschule, Hannover vorgestellt. Vorberichtlich war das Pferd mindestens fünf Jahre zuvor kastriert worden. In der linken Inguinalregion lag am kaudalen Ende des Präputiums eine diffuse, in der Tiefe derbe Schwellung vor. Die Haut in diesem Bereich war intakt. Eine transkutane ultrasonographische Untersuchung dieses Bereiches lieferte Hinweise auf ein Ödem der Unterhaut sowie auf eine rundliche, in Richtung des äußeren Leistenringes ziehende und in der Tiefe schlecht abgrenzbare Struktur mit einer hyperechogenen Kapsel und einem hypoechogenen Zentrum mit läppchenartigen hyperechogenen Arealen. Nach chirurgischer Entfernung sowie pathohistologischer und bakteriologischer Untersuchung der Umfangsvermehrung wurde die Diagnose einer chronischen Staphylococcus aureus infection (Botryomycose) gestellt. Dieser Fallbericht beschreibt die Diagnostik und die erfolgreiche chirurgische und antimikrobielle Behandlung dieser heutzutage seltener berichteten Langzeitkomplikation nach Kastration.

Schlüsselwörter: Pferd / Kastration / Komplikation / Samenstrang / Granulom / Staphylococcus aureus / Botryomykose

Citation: Conze P., Beineke A., Mietze A, Geburek F. (2015) Diagnosis and surgical treatment of a chronic Staphylococcus aureus infection (botryomycosis) as a long-term complication after castration - a case report. Pferdeheilkunde 31, 11-19

Correspondence: Dr. F. Geburek, Dipl. ECVS, Clinic for Horses, University of Veterinary Medicine Hannover Foundation, Bünteweg 9, 30559 Hannover, Germany, E-Mail: florian.geburek@tiho-hannover.de

\section{Introduction}

Complications which may arise following castration can generally be divided into short-term and long-term complications. Complications that occur within a few hours up to a few days after castration include haemorrhage, evisceration, oedema, peritonitis, penile trauma or paralysis, and priapism (Cox 1978, Nickels 1988, Oehme 1988, Schumacher 1996, Gerhards 2003, Shoemaker et al. 2004, Kilcoyne et al. 2013). Long-term complications are comprised of wound infections, including infection of the spermatic cord, hydrocele and unaltered stallion-like behaviour (Cox 1978, Nickels 1988, Oehme 1988, Moll et al. 1995, Schumacher 1996, May and Moll 2002, Gerhards 2003, Shoemaker et al. 2004, Mason et al. 2005). Septic funiculitis might be caused by an ascending extension of scrotal infection with Staphylococcus spp., Streptococcus spp. or other commensal bacteria after castration, or by a contaminated emasculator or suture material (Bolz et al. 1968, Joest 1985, Schumacher 1996, Gerhards 2003, Schumacher 2012). Open ans semiclosed castration techniques might predispose for infection of the spermatic cord (O'Connor 1938, Mason et al. 2005, Kilcoyne et al. 2013), but septic funiculitis can also occur after castration using closed techniques (Schumacher 2012). Septic funiculitis is characterized either by a chronic draining tract or the scrotal incision might heal while the infected spermatic cord enlarges with granulation tissue. The formation of an abscess or microabscess, typically seen in pyogranulomatous conditions, might occur and lead to draining tracts towards the skin surface within the inguinal region.

Spermatic cord infections caused by Streptococcus spp. in open castration wounds are misleadingly referred to as "Champignon" (French word for "mushroom") (Wright 1963, Cox 1978, Nickels 1988, Oehme 1988). Clinical signs of this condition usually develop two to three weeks after surgery. The spermatic cord becomes swollen and turgid, followed by abscessation. Horses show signs of acute illness, such as pyrexia, preputial and scrotal oedema, and become painful to pal- 
pation of the region affected (Nickels 1988, Fitch and Schumacher 1996). The name "champignon" reflects the concurrent exuberant granulation tissue formation which may ultimately protrude from the scrotal wound (Wright 1963, Cox 1978, Nickels 1988, Oehme 1988). This is a rather non-specific morphologic phenomenon which may accompany draining tracts in cases of persisting spermatic cord infections (Vogel 1891). The use of non-absorbable suture material, such as silk, whip cord or absorbable catgut ligature, is supposed to represent a predisposing factor for this condition (Wright 1963, Nickels 1988, Oehme 1988, Colahan et al. 1999).

A granuloma may develop in cases of persistent foreign body reaction to non-absorbable suture material or infectious agents. In some cases, the pathology might not become clinically apparent until several years after castration (Hutyra ef al. 1945, Cox 1978, Fitch and Schumacher 1996). Chronic granulomatous funiculitis is, therefore, clinically characterized by a large painless swelling in the inguinal and scrotal area with or without sinus tracts discharging purulent exudate (Frank 1964, Cox 1978, Joest 1985, Schumacher 2012). A stump of the spermatic cord chronically infected with pyogenic bacteria is also commonly referred to as scirrhous cord (Frank 1964, Schumacher 2012). If Staphylococcus aureus is identified as the infectious agent, the condition is also referred to as botryomycosis (De Jong 1899, Joest 1924, Hutyra et al. 1945, Cox 1978, Joest 1985, Gerhards 2003, Smiet et al. 2012). A possible sequela of the enlargement of the spermatic cord might be hind limb lameness caused by mechanical interference with the locomotion or pain due to an acute flare-up of the infection (Wright 1963, Nickels 1988, Echte et al. 2006, Schumacher 2012). Transcutaneous ultrasonography and bacteriological and histopathological examination will aid the establishment of the diagnosis. The case presented here describes the clinical presentation, diagnosis and successful treatment of botryomycosis as a longterm complication after castration.

\section{Case report}

Case history

An eight-year-old gray Mecklenburger warmblood gelding was presented at the Clinic for Horses, University of Veterinary Medicine Hannover, Foundation, for evaluation of a swelling and oedema of the prepuce and mild hind limb gait abnormality. The swelling of the prepuce had been noted by the owner a few weeks prior to admission and the hind limb gait abnormality had become more obvious with the increase of the size of the swelling. There was no history of draining or exudation from the inguinal region. The owner had purchased the horse approximately five years previously. At that time point, the horse had already been castrated. Data about castration technique and suture material used were not available. The horse was referred for further evaluation and surgery if applicable.

\section{Clinical examination}

General physical examination on admission was unremarkable. Haematocrit (33.7\%), total protein (74 g/l) and leucocy- tes $(7.6 \mathrm{~g} / \mathrm{l})$ were within normal limits. During examination of the genital tract, the left side of the prepuce showed a diffuse swelling. On palpation, the subcutis was oedematous with a firm mass underneath, starting approximately $12 \mathrm{~cm}$ caudally to the preputial orifice extending dorsally to the inguinal ring where it could not be demarcated by palpation. The visible swelling was about $8 \times 5 \times 2 \mathrm{~cm}$ in size (Fig. 1). The horse showed no signs of pain or discomfort during palpation. A castration scar was present on the right side of the scrotum. However, no fistula or sinus tracts and no exudation were detectable in the inguinal region. Examination of the penis showed no abnormalities. Transcutaneous ultrasonographic examination of the prepuce and the inguinal region showed oedematous subcutaneous tissue and a spherical, moderately demarcated mass with a thick capsule subdivided into echoic lobes and a hypoechoic to anechoic centre (Fig. 2). The echo pattern of the centre was not characteristic of purulent material. A prominent blood vessel was located centrally within the mass. No abnormalities of the internal inguinal rings or the caudal abdomen were noted on rectal palpation. Mild activation and enlargement of the superficial inguinal lymph
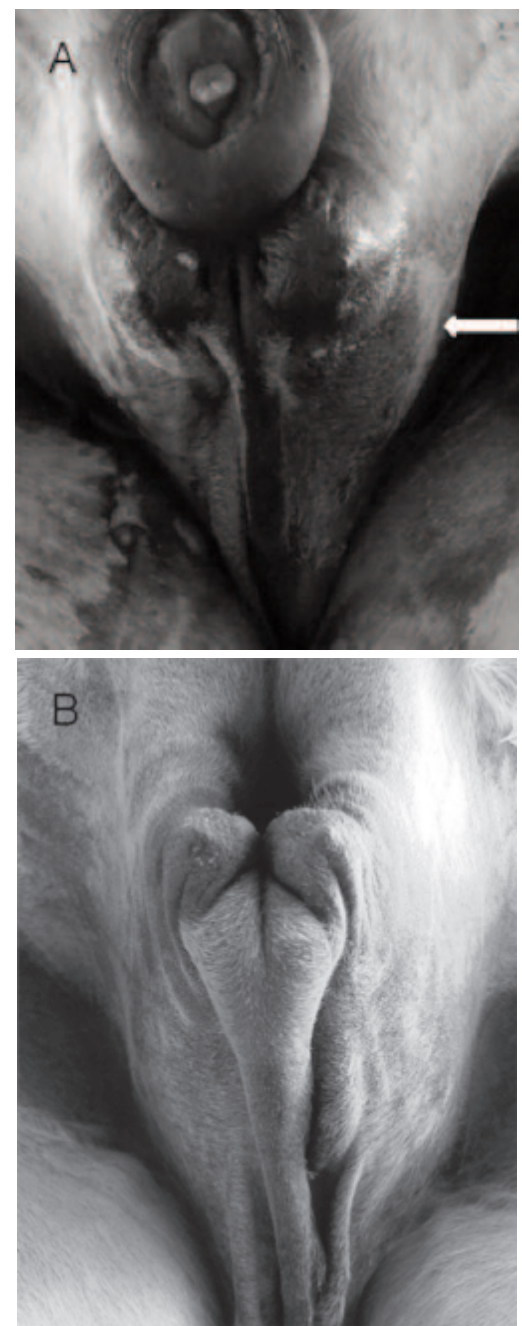

Fig. 1 Ventral view of the preputial and inguinal region pre-surgery and 10 months post-surgery. A) Pre-surgery a diffuse swelling of the prepuce pronounced on the left side is evident (arrow). B) There is no swelling visible ten months post-surgery.

Ventrale Ansicht auf das Präputium und die inguinaleregion vor und nach der Operation. A) Das Praeputium weist eine links besonders akzentuierte, diffuse Schwellung auf (Pfeil). B) Zehn Monate nach der Operation ist keine Schwellung mehr feststellbar. 
nodes and the medial iliac lymph nodes (Fig. 3) were suspected during transcutaneous and transrectal ultrasonography, respectively. The horse showed grade 1/5 left hind limb lameness at a trot (grade $0 / 5$ being sound and grade $5 / 5$ being non-weight-bearing lame). The differential diagnoses at that time point were neoplasia, chronic abscessation or granulomatous funiculitis.

\section{Biopsy}

Fine-needle biopsies were taken of the enlarged structure within the inguinal region and of the superficial inguinal lymph nodes for diagnostic reasons. For the procedure, the horse was restrained in stocks and sedated with $0.03 \mathrm{mg} / \mathrm{kg}$ IV detomidine (Cepesedan ${ }^{\circledR}, \mathrm{CP}$ Pharma, Burgdorf, Germany) and $0.01 \mathrm{mg} / \mathrm{kg}$ IV butorphanol (Alvegesic ${ }^{\circledR}$, Vet $10 \mathrm{mg} / \mathrm{ml}$, CP

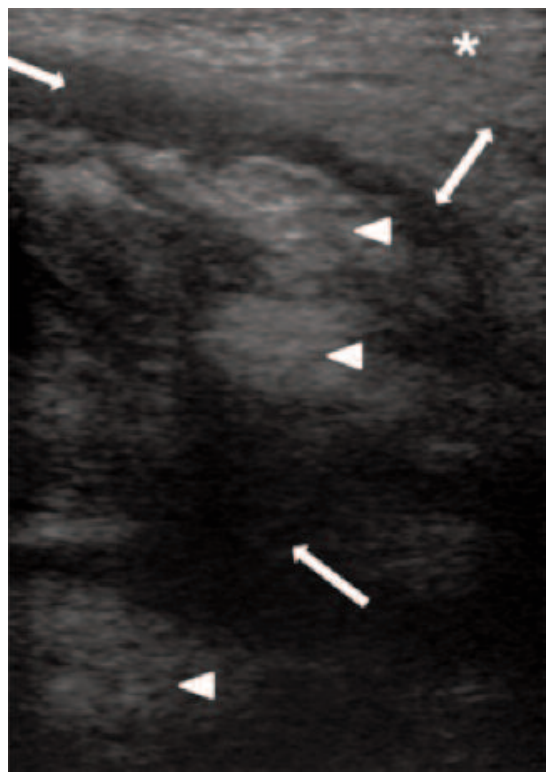

Fig. 2 Transcutaneous ultrasonography of the left inguinal region (longitudinal probe position). Oedematous subcutaneous tissue (asterisk); fibrous capsule (double arrow); core of the mass consisting of partly echoic lobes (arrow head) and partly hypoechoic to anechoic areas (arrow).

Transkutanes Ultrasonogramm der linken Inguinalregion (longitudinale Anschallposition). Subkutanes Ödem (Stern), bindegewebige Kapsel (Doppelpfeil); teils echoreicher, läppchenartiger (Pfeilspitzen), teils hypoechogener (Pfeile) Inhalt der Zubildung.

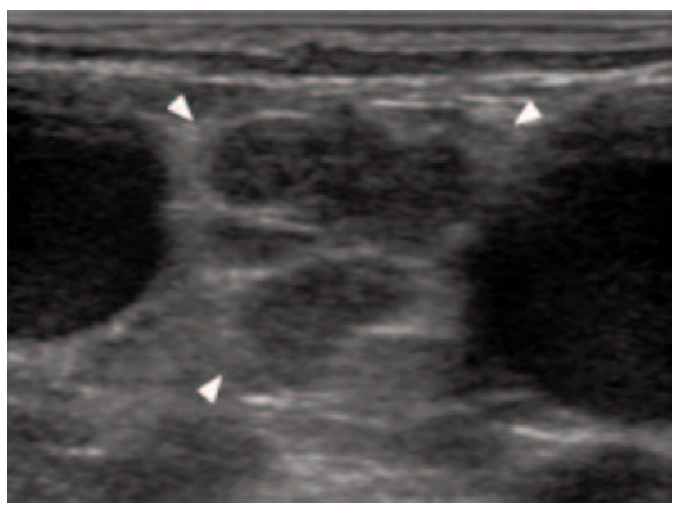

Fig. 3 Trans-rectal ultrasonography of the aortic bifurcation. Activated medial iliac lymph nodes (white arrow heads).

Transrektales Ultrasonogramm der Aortenaufzweigung. Aktivierte Lymphonodi iliaci mediales (Pfeilspitzen).
Pharma, Burgdorf, Germany). Two millilitres of local anaesthetic (Scandicain ${ }^{\circledR}$ 2\%, AstraZeneca, Wedel, Germany) were injected subcutaneously before a stab incision was made with a number 11 scalpel blade over the centre of the lesion. A Pro-Mag ${ }^{\text {TM }}$ Automatic Biopsy Instrument (Manan Pro-Mag ${ }^{\text {TM }}$ 2.2, Manan, USA) with a $18 \mathrm{~g}$ core biopsy needle was utilised under ultrasonographic guidance for needle biopsy harvesting. The horse received Trimethoprim $120 \mathrm{mg} / \mathrm{g}+$ Sulfadiazin $600 \mathrm{mg} / \mathrm{g}$ (Synutrim ${ }^{\circledR} 72 \%$, Vétoquinol GmbH, Ravensburg, Germany) $30 \mathrm{mg} / \mathrm{kg}$ twice daily per os for three days. Pathology revealed collagen-rich connective and adipose tissue with chronic inflammation and fibrosis. No lymphatic tissue was seen and there was no evidence of neoplasia.

\section{Treatment}

The decision for surgical removal of the mass under general anaesthesia in dorsal recumbency was made. After premedication with acepromazine (Vetranquil ${ }^{\circledR}$, CEVA Tiergesundheit, Düsseldorf, Germany) $0.03 \mathrm{mg} / \mathrm{kg}$ IM, xylazine (Xylazin $2 \%$, CP Pharma, Burgdorf) $0.8 \mathrm{mg} / \mathrm{kg} \mathrm{IV}$ and butorphanol (Alvegesic $^{\circledR}$, Vet $10 \mathrm{mg} / \mathrm{ml}$, CP Pharma, Burgdorf, Germany)

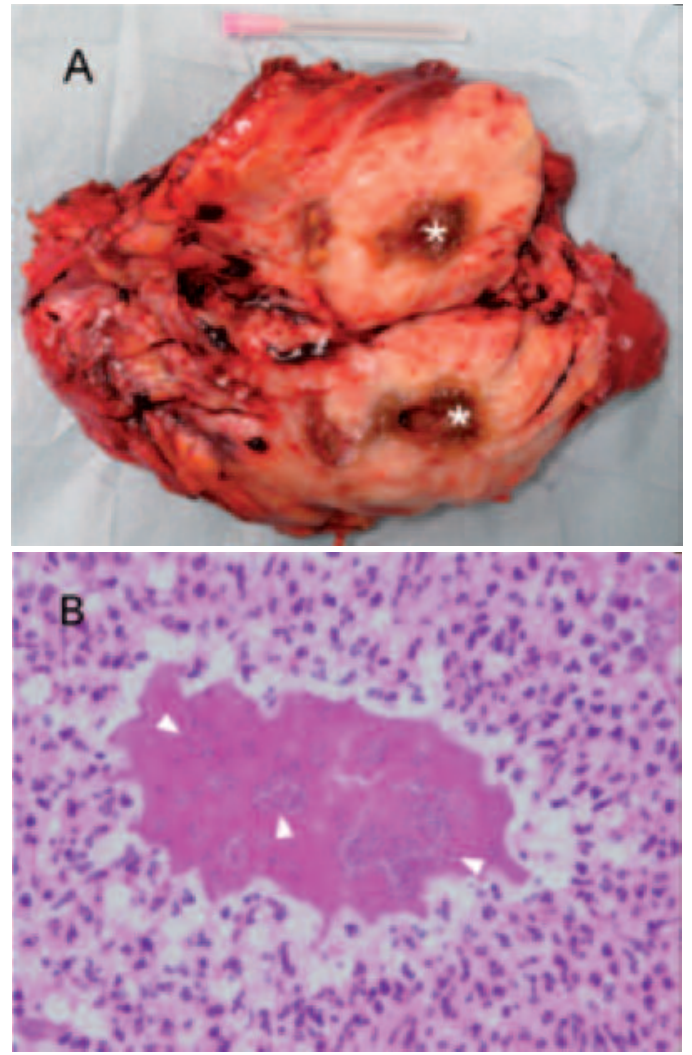

Fig. 4 Excised, longitudinally cut granuloma. A) Macroscopic view with centrally located necrosis (asterisk) surrounded by dense fibrous capsule and loose granulation tissue; B) Photomicrograph showing a sulphur granule. Colonies of bacteria (arrow heads) are surrounded by an eosinophilic material (Splendore-Hoeppli material) and numerous neutrophils ( $\mathrm{HE}, 400 \times$ magnification)

Das entfernte Granulom im Längsschnitt. A) Makroskopische Ansicht mit zentral gelegenen Nekrosen (Sterne), umgeben von einer derben bindegewebigen Kapsel und lockerem Granulationsgewebe. B) Mikroskopisches Bild einer Druse; Bakterienkolonien (Pfeilspitzen) umgeben von eosinophilem Material (Splenore-Hoeppli-Material). Im umgebenden Gewebe befinden sich massenhaft neutrophile Granulozyten (HE-Färbung 400-fache Vergrößerung). 
$25 \mu \mathrm{g} / \mathrm{kg}$ IV anaesthesia was induced with ketamine (Narke$\tan ^{\circledR}, 100 \mathrm{mg} / \mathrm{ml}$, Vétoquinol, Ravensburg, Germany) $2.2 \mathrm{mg} / \mathrm{kg}$ IV and midazolam (Midazolam $15 \mathrm{mg} / \mathrm{ml}$, Braun Melsungen, Germany) $0.05 \mathrm{mg} / \mathrm{kg} \mathrm{IV}$, and maintained with isoflurane (Isofluran $\mathrm{CP}^{\circledR}, \mathrm{CP}$ Pharma, Burgdorf, Germany) in $100 \%$ oxygen and a constant rate infusion of $0.8 \mathrm{mg} / \mathrm{kg} / \mathrm{h}$ xylazine. Lactated Ringers solution (Ringer-Laktat-Lösung ${ }^{\circledR}, B$. Braun, Melsungen AG, Germany) was administered at a rate of $5 \mathrm{ml} / \mathrm{kg} / \mathrm{h}$ and dobutamine (Dobutamin-ratiopharm $250 \mathrm{mg} / 50 \mathrm{ml}$, Ratiopharm, Ulm, Germany) was given to effect to maintain a mean arterial blood pressure of greater than $70 \mathrm{mmHg}$. After pre-surgical aseptic preparation of the inguinal area, a $15 \mathrm{~cm}$ long cranio-caudal, slightly s-shaped skin incision was made over the centre of the mass in the left inguinal area. The firm mass, which was spherical ventrally and funnel-shaped dorsally, was isolated from the surrounding tissue via blunt and sharp dissection, until a mature adhesion to the vaginal process and the remnants of the spermatic cord became evident. Monopolar electrocautery and a bipolar electrosurgical vessel sealing device (LigaSure Atlas ${ }^{\mathrm{TM}}$ $20 \mathrm{~cm}$ Hand Switching Open Instrument, Tyco Healthcare UK Ltd., Gosport, UK) were used for haemostasis. The exposed vaginal process was incised and the spermatic cord was exposed. After separate ligation of the Ductus deferens and the pampiniform plexus together with the testicular artery with transfixation ligature $\left(\right.$ Vicryl ${ }^{\circledR} 2$ USP, Ethicon ${ }^{\circledR}$, Johnson \& Johnson Medical, Norderstedt, Germany) as proximal to the mass as possible, these structures were transected using the bipolar electrosurgical vessel sealing device and a Serra emasculator, respectively.

The vaginal process was closed separately with a transfixation ligature $\left(\right.$ Vicryl ${ }^{\circledR} 1$ USP, Ethicon ${ }^{\circledR}$, Johnson \& Johnson Medical, Norderstedt, Germany) and transected using a Serra emasculator. After copious flushing of the wound with cooled sterile physiologic saline $\left(\mathrm{NaCl} 0.9 \%\right.$ Ecotainer $^{\circledR}$, B. Braun Melsungen AG, Melsungen, Germany), a gauze tamponade was placed within the wound leading out through a separate, $2 \mathrm{~cm}$ long incision, located cranially to the main wound. The gauze tamponade was sutured to the skin using nylon suture (Dafilon $^{\circledR} 1$ USP, B. Braun Melsungen AG, Melsungen, Germany). The wound was closed in three layers, each with a simple continuous suture pattern and polyglactin 910 suture (Vicryl ${ }^{\circledR} 1$ USP and Vicryl ${ }^{\circledR}$ 2-0 USP, Ethicon ${ }^{\circledR}$, Johnson \& Johnson Medical, Norderstedt, Germany). Perioperatively, the horse received $10 \mathrm{mg} / \mathrm{kg}$ amoxicillin IV twice daily (Belamox ${ }^{\circledR}$, Amoxicillin-Natrium, bela-pharm $\mathrm{GmbH} \&$ Co. KG, Vechta, Germany) and $1.1 \mathrm{mg} / \mathrm{kg}$ flunixin-meglumine, initially IV, later per os (Flunidol ${ }^{\circledR}$ RPS $50 \mathrm{mg} / \mathrm{ml}$ or Flunidol ${ }^{\circledR} 5 \%$, CP-Pharma, Burgdorf, Germany). The antibiotic treatment was continued for a further five days; the flunixin-meglumine treatment was reduced to half a dose twice daily after four days and discontinued after six days. Half of the gauze tamponade was removed from the wound through the separate incision after 48 hours; the remaining half was left in place for another 12 hours. The small incision through which the tamponade was removed was left to heal by second intention.

\section{Pathological and microbiological findings}

The excised chronically enlarged spermatic cord residual was sent to the Department of Pathology, University of Vete- rinary Medicine Hannover, Foundation, for histopathological evaluation. Samples for bacteriologic testing were sent to the Institute for Microbiology, University of Veterinary Medicine Hannover, Foundation. Histologically, parts of the ductus deferens were found within the mass. A pyogranulomatous inflammation and multifocal granulomas with SplendoreHoeppli material encasing intralesional bacteria were evident in the adjacent adipose tissue (Fig. 4). Multifocal areas of necrotic tissue within the granulation tissue were also present. Remnants of foreign body material were not identified. Large quantities of Staphylococcus aureus were cultured from the bacterial swabs. The bacteriologic sensitivity testing revealed susceptibility to most commonly used antibiotics, among these amoxicillin and trimethoprim-sulfadiazine. The histopathological and bacteriological diagnosis of Botryomycosis was made.

\section{Outcome}

The main wound was adapted and without exudation six days after surgery. Mild sero-sanguinous discharge was present at the separate incision which was left open for drainage and second intention healing. Oedema of the prepuce and inguinal area was still evident. After antibiotic susceptibility testing, the antibiotics were switched from IV amoxicillin to oral application of trimethoprim sufadiazine (Synutrim ${ }^{\circledR} 72 \%$ Pulver, Thrimetoprim $120 \mathrm{mg} / \mathrm{g}$ + Sulfadiazin $600 \mathrm{mg} / \mathrm{g}$, Vétoquinol $\mathrm{GmbH}$, Ravensburg, Germany) six days post-surgery. The owners were instructed to continue the antibiotic treatment for another three weeks and to keep the gelding at box rest for the initial 14 days. Ten minutes of daily handwalking seven days after surgery was recommended. Thereafter, the horse received additional paddock turnout for another two weeks. Two weeks after discharge (i.e. three weeks after surgery) the owner and referring veterinarian reported a good healing progress: the main incision had healed by first intention healing and no further discharge was noted from the separate incision. Slight inguinal and preputial oedema was still present.

The owner reported in a telephone conversation nine months after surgery, that the horse was back in full training, thriving and lameness was no longer evident. The wound had healed completely without any oedema. Re-examination about one year after presentation at the Clinic for Horses, University of Veterinary Medicine Hannover, Foundation, showed no abnormalities at general physical examination. Lameness was especially not evident at walk, trot or canter and the inguinal and preputial region showed no visible or palpable abnormal findings.

\section{Discussion}

In this case report, the diagnosis, treatment and successful outcome of chronic granulomatous funiculitis caused by Staphylococcus aureus as a nowadays seldom reported longterm sequela of castration are presented (Überreiter 1938, Frank 1964, Cox 1978, Nickels 1988, Schumacher 1996, Gerhards 2003).

Botryomycosis of the spermatic cord remnant is reported to be caused by chronic, low-grade infection with Staphylococcus 
aureus (De Jong 1899, Joest 1924, Hutyra et al. 1945, Joest 1985, Gerhards 2003, Smiet et al. 2012) or other staphylococcal species (Wright 1963, Cox 1978, Nickels 1988, Oehme 1988, Colahan et al. 1999, Sleeman et al. 2003). The use of silk and nylon ligatures, contaminated suture material, multiple crushing of the cord stump, and an oblong spermatic cord remnant are presumed as disposing factors. Correlations to closed or open techniques could not be proved so far (Bolz et al. 1968, Colahan et al. 1999, Gerhards 2003, Echte et al. 2006, Kilcoyne et al. 2013). However, information about the date of surgery and technique of castration were not available in the present case. Since the owner was in possession of this horse for over five years, the horse must have been castrated within its first three years of life. Remnants of suture material could not be found within the mass. Circumstances other than castration have not been described in literature as causative for this pathology in the inguinal region. The owner realised the swelling only a few weeks before admission. This proves that the pathology might not become clinically apparent until several years after castration (Hutyra et al. 1945, Cox 1978, Fitch and Schumacher 1996).

Cutaneous and visceral forms of botryomycosis occur in humans and animals (Joest 1924, Kitt 1924, Hutyra et al. 1945, Winslow 1959, Speir et al. 1971, Cox 1978, Joest 1985, Oehme 1988, Padilla-Desgarennes et al. 2012). The condition was first described in the horse as a granulomatous lesion in the lung by Bollinger in 1870 (Bollinger 1870, Joest 1924, Winslow 1959, Smiet et al. 2012). The name botryomycosis was created because of the erroneously suspected fungal genesis and the grape-like appearance of the granules (Winslow 1959, Smiet et al. 2012). In the late-19th and early-20th century, De Jong (1899), Galli-Valerio and Kitt (cited by Joest 1924) were able to isolate cocci identical to Staphylococcus aureus out of botryomycotic lesions. Magrou (1919) as well as Kimmelstiel and Easley (1940) proofed the bacterial, more specifically Staphylococcus aureus, related etiology by experimental induction of botryomycotic conditions in rabbits (see also Winslow 1959, Smiet et al. 2012). Kimmelstiel and Easley (1940), furthermore, stated that a typical botryomycotic lesion was not caused by infection of Staphylococcus aureus alone, but by staphyloccocal infection together with a predisposing factor, such as an inoculated foreign body.

The exact pathogenesis is still unclear, but it seems that the development of botryomycosis depends upon the virulence of the causative agent, the inoculum's size, the presence of foreign bodies, and the host's immune response (Kimmelstiel and Easley 1940, Saadat et al. 2008, Smiet et al. 2012). Since some Staphylococccus aureus isolates from botryomycotic lesions were observed to show low virulence in experimental animal models (Kimmelstiel and Easley 1940, Winslow 1959), an increase in the resistance of the host's immune system in combination with a relative decrease in virulence of the bacteria might be part of the pathomechanism (Drake et al. 1943, Winslow 1959). Bacteria in botryomycosis are grouped together in clusters in the form of grains or granules as a strategy to escape the host's immune response or to resist antibiotic treatment, respectively (Padilla-Desgarennes et al. 2012, Smiet et al. 2012). Formation of radiate, star-like or club-shaped eosinophilic material, presumably consisting of antigen-antibody complex, cell debris, glycoproteins, lipids, and calcium derived from leucocytes around the cau- sative bacteria, is called the Splendore-Hoeppli phenomenon (Padilla-Desgarennes et al. 2012, Smiet et al. 2012). Prevention of phagocytosis and intracellular killing of the bacteria is thought to lead to persistent infection and chronic inflammation, respectively (Hussein 2008). In this case, a characteristic histomorphological pattern (Share and Utroska 2002, Sleeman et al. 2003, Smiet et al. 2012) in combination with isolation of Staphyloccocus aureus by microbiological testing led to the diagnosis of botryomycosis.

In the present case, oedematous swelling of the preputial and inguinal area together with a firm, poorly demarcated mass, the chronic disease course and hind limb lameness were typical features of chronic septic or granulomatous funiculitis (Nikkels 1988). However, similar lesions can be observed in neoplastic processes, such as malignant melanoma, fibrosarcoma or squamous cell carcinoma (Seltenhammer et al. 2003, Van Den Top et al. 2010, Phillips and Lembcke 2013). Although the penis was without pathological findings at clinical examination, neoplasms have to be considered as a differential diagnosis, which has to be excluded by histopathology. The fact that discharging sinus tracts, which are often recognised in cases of scirrhous cord formation, were not present in the case described here, however, made it more difficult to exclude neoplasia (Cox 1978, Fitch and Schumacher 1996).

Transcutaneous ultrasound findings of the case described here were ambiguous. The capsulated structure with centrally located hypoechoic material, probably representing fluid, was not clearly characteristic of a neoplastic lesion. A more lobular pattern would have been expected in the case of neoplasia (Matiasek et al. 2007). The hypoechoic regions did not show the typical appearance of purulent material. In this case, hyperechoic floating spots should have been detectable within the hypoechoic fluid. The suspected mild activation and enlargement of the superficial inguinal (seu scrotal) lymph nodes and the medial iliac lymph nodes could have been triggered by chronic inflammation or might also have been an early sign of regional metastases of neoplasia. Even though ultrasound is a potentially valuable technique for examination of soft tissue masses, in this case, neither chronic accumulation of pus nor neoplasia could have been ruled out with certainty.

A needle biopsy was performed in an attempt to further exclude possible differential diagnoses. The histopathological results were non-specific, no lymphatic tissue was seen and there was no evidence of neoplasia. It is most probable that subcutaneous tissue and part of the fibrous capsule of the granulomatous tissue were harvested. Potentially false negative results after needle biopsies are a well-known limitation of this technique and had been discussed with the owner in advance. A positive biopsy result was considered to be more probable in the case of neoplasia, although neoplasias are frequently encapsulated by fibrous tissue, so that a non-neoplastic origin of the mass was considered slightly more plausible and the advice for surgery was given.

Hind limb gait abnormalities are reported as potential consequences of disorders in the inguinal region, e.g. scirrhous cord (Echte et al. 2006). In the present case, the origin of the mild left hind limb lameness was not localized with diagnostic nerve blocks. Therefore, the presence of a coincidental ortho- 
paedic pathology cannot be excluded as an alternative reason for the lameness. The total disappearance of the lameness post-convalescence could be attributable either to box rest and a controlled exercise programme during recovery, or to successful surgical treatment of the chronic septic funiculitis, which, in the authors' opinion, is more plausible due to the mild degree of the lameness and the owner's observation that the gait abnormality increased with the swelling in the inguinal region. In the latter case, the lameness may have been caused either by pain or by mechanical interference with the normal gait cycle.

Surgical therapy is the treatment of choice in cases of botryomycosis because Staphylococcus aureus colonies are not accessible by standard antibiotics due to the bacterial encapsulation by granulomatous inflammation with fibrosis and Splendore-Hoeppli material. In the present case, the granulomatous mass was resected in total without inadvertent exposure of its core to the surgical field. Antibiotic treatment was continued for four weeks after surgery to minimise the risk of reinfection since suture material, although resorbable, was used for ligation of the spermatic cord and the vaginal process. A mere transection and sealing of both structures with the vessel sealing device was considered as potentially insufficient in this case, due to the fact that the horse was eight years old and was attended by relatively large anatomic structures that had to be closed safely. Electrosurgery, however, significantly facilitated resection from the surrounding tissues, which is potentially time-consuming in chronic inflammatory processes, due to the firm consistency of the mature granulation tissue containing numerous blood vessels.

In conclusion, this case report shows that surgical excision with accompanying systemic application of antimicrobials was a successful concept for treatment of a chronic septic funiculitis after castration caused by Staphylococcus aureus infection (botryomycosis) and should be considered as a first choice approach for this pathology.

\section{Acknowledgements}

The authors would like to thank Dr. Michael Feilke who referred this case to the Clinic for Horses of the University of Veterinary Medicine Hannover, Foundation and Dr. Klaus Hopster, Dipl. ECVAA, who performed the anaesthesia.

\section{References}

Bollinger O. (1870) Mycosis der Lunge beim Pferde. Virchows Arch. path. Anat. 49, 583-586

Bolz W., Dietz O., Schleiter H., Teuscher R. (1968) Krankheiten des Funiculus spermaticus und der Tunica vaginalis, Lehrbuch der Speziellen Veterinärchirurgie Teil II, Gustav Fischer Verlag, Stuttgart, 495-498

Colahan P. T., Mayhew I. G., Merritt A. M., Moore J. N. (1999) Reproduktive System: The stallion, Equine Medicine and Surgery, Mosby, St. Louis, 5th Edition, 1027

Cox J. E. (1978) Surgery of the Reproductive Tract in large Animals, Liverpool University Press, Liverpool, 16-36

De Jong D. A. (1899) Untersuchungen über Botryomyces. Diss. Med. Vet. Giessen

Drake C. H., Sudler M. T., Canuteson R. I. (1943) A case of staphylococcic actinophytosis (botryomycosis) in man: The tenth reported 3human case. J. Am. Med. Assoc. 123, 339-341
Echte A.-F., Schmidt-Ott C., Claaßen W., Heczko K., Gremmes C., Gremmes S. (2006) Durch Verwachsung des Samenstranges hervorgerufene Hinterhandlahmheit beim Pferd - eine Spätkomplikation der Kastration. Pferdeheilkunde 22, 445-448

Fitch G., Schumacher J. (1996) Infection of the spermatic cord of a pony gelding, Equine vet. Educ. 8, 251-252

Frank E. R. (1964) Affections of the Tail, Anus, Rectum, Vagina and Penis. Veterinary Surgery, Burgess Publishing Company, Minneapolis, 275

Gerhards H. (2003) Kastrationskomplikationen und Möglichkeiten zu deren Vermeidung: Chirurgische und forensische Betrachtungen. Pferdeheilkunde 19, 37-44

Hussein M. R. (2008) Mucocutaneous Splendore-Hoeppli phenomenon. J. Cutan. Pathol. 35, 979-988

Hutyra F., Marek J., Manninger R. (1945) Spezielle Pathologie und Therapie der Haustiere. Gustav Fischer, Jena, 586-590

Joest E. (1924) Spezielle pathologische Anatomie der Haustiere. Verlagsbuchhandlung von Richard Schoetz, Berlin, Dritter Band, 170 $175,802-804$

Joest E. (1985) Genitalorgane, Haut, Skelett. In: Handbuch der Speziellen Pathologischen Anatomie der Haustiere. Paul Parey, Berlin, 3. Auflage, 4. Band, 46-59

Kilcoyne I., Watson J. L., Kass P., H., Spier S. J. (2013) Incidence, management, and outcome of complications of castration in equids: 324 cases (1998-2008). J. Am. Vet. Med. Assoc. 24, 820-825

Kimmelstiel P., Easley C. A. (1940) Experimental botryomycosis. Am. J. Pathol.16, 95-101 102

Kitt T. (1924) Lehrbuch der Pathologischen Anatomie der Haustiere. Verlag von Ferdinand Enke, Stuttgart, 5. Neubearbeitete Auflage, 200-202, 298-299, 338-339, 470-471

Magrou J. (1919) Les formes actinomycotiques du staphylocoque. Ann. Inst.Pasteur. (Paris) 33, 344-374

Mason B. J., Newton J. R., Payne R. J., Pilsworth R. C. (2005) Costs and complications of equine castration: a UK practice-based study comparing 'standing nonsutured' and 'recumbent sutured' techniques. Equine Vet. J. 37, 468-472

Matiasek K., Cronau M., Schmahl W., Gerhards H. (2007) Imaging Features and Decision Making in Retrobulbar Neuroendocrine Tumours in Horses - Case Report and Review of Literature. J. Vet. Med. Assoc. 54, 302-306

May K. A., Moll H. D. (2002) Recognition and management of equine castration complications. Compendium on Continuing Education for the Practicing Veterinarian 24, 150-162

Moll H. D., Pelzer K. D., Pleasant R. S., Modransky P. D. (1995) A survey of equine castration complications. J. Equine Vet. Sci. 15, 522-526

Nickels F. A. (1988) Complications of castration and ovariectomy. Vet. Clin. North Am. Equine Pract. 4, 515-523

O'Connor J. J. (1938) Dollar s Veterinary Surgery. Alexander Eger, Chicago, 1874

Oehme F. W. (1988) Textbook of Large Animal Surgery, Williams \& Wilkins, Baltimore, 518-519

Padilla-Desgarennes C., Vazquez-Gonzalez D., Bonifaz A. (2012) Botryomycosis. Clin. Dermatol. 30, 397-402

Phillips J. C, Lembcke L. M. (2013) Equine Melanocytic Tumors. Vet. Clin. North Am. Equine Prac. 29, 673-687

Saadat P., Ram R., Sohrabian S., Vadmal M. S. (2008) Botryomycosis caused by Staphylococcus aureus and Pneumocystis carinii in a patient with acquired immunodeficiency disease. Clin. Exp. Dermatol. 33, 266-269

Schumacher J. (1996) Complications of castration. Equine Vet. Educ. 8, 254-259

Schumacher J. (2012). Testis. In: Equine Surgery. Auer, J. A., Stick, J. A. (eds.), Elsevier Saunders, St. Louis, Fourth Edition, 804-840

Seltenhammer M. H., Simhofer H., Scherzer S., Zechner P., Curik I., Sölkner J., Brandt S. M., Jansen B., Pehamberger H., Eisenmenger E. (2003) Equine melanoma in a population of 296 grey Lipizzaner horses. Equine Vet. J. 35, 153-157

Share B., Utroska B. (2002) Intra-abdominal botryomycosis in a dog. J. Am. Vet. Med. Assoc. 220, 1025-1027 
Shoemaker R., Bailey J., Janzen E., Wilson D. G. (2004) Routine castration in 568 draught colts: incidence of evisceration and omental herniation. Equine Vet. J. 36, 336-340

Sleeman J. M., Clyde V. L., Finnegan M. V., Ramsay E. C., Shires M. G. (2003) Mammary botryomycosis and mastectomy in an African elephant (Loxodonta africana). Vet. Rec. 152, 54-55

Smiet E., Grinwis G. C. M., van den Top J. G. B., Sloet van Oldruitenborgh-Oosterbaan M. M. (2012) Equine mammary gland disease with a focus on botryomycosis: A review and case study. Equine Vet. Educ. 24, 357-366

Speir W. A. Jr., Mitchener J. W., Galloway R. F. (1971) Primary pulmonary botryomycosis. Chest 60, 92-93

Überreiter O. (1938) Fortschritte der neuzeitlichen Veterinärchirurgie Festschrift Theodor Schmidt zu seinem Siebzigsten Geburtstage gewidmet von seinen Schülern und Freunden. Verlag von Urban \& Schwarzenberg, Berlin und Wien, 188-198

Van Den Top J. G. B., Ensink J. M., Gröne A., Klein W. R., Barneveld A., van Weeren P. R. (2010) Penile and preputial tumours in the horse: Literature review and proposal of a standardised approach. Equine Vet. J. 42, 746-757

Vogel E. (1891): Hering's Operationslehre für Tierärzte, 5. Aufl., Verlag von Schickhardt und Ebner, Konrad Wittwer, Stuttgart, 578585

Winslow D. J. (1959) Botryomycosis. Am. J. Pathol. 35, 153-167

Wright J. G. II.(1963) The Surgery of the Inguinal Canal in Animals. Vet. Rec. 75, 1352-1363

\section{Erweiterte Zusammenfassung}

In Folge einer Kastration können sich Kurz- und Langzeitkomplikationen einstellen. Blutungen, Darmvorfälle, Wundödeme, Bauchfellentzündungen sowie Penisverletzungen und Priapismus treten zumeist innerhalb weniger Stunden bzw. Tage auf. Persistierendes hengstartiges Verhalten, Hydrozelen und Wundinfektionen hingegen zeigen sich erst im weiteren Verlauf. Eine septische Samenstrangentzündung (Funikulitis) kann durch aufsteigende Wundinfektionen mit Staphylococcus spp., Streptococcus spp., anderen Kommensalen oder durch kontaminierte Instrumente bzw. kontaminiertes Nahtmaterial verursacht werden. Kastrationstechniken ohne Wiederverschluß des Scheidenhautfortsatzes und der Haut begünstigen aufsteigende Wundinfektionen, allerdings können septische Samenstrangentzündungen auch nach Anwendung geschlossener Operationstechniken auftreten. Im angelsächsischen Sprachraum wird eine durch Streptokokken verursachte Funikulitis irreführenderweise auch als "Champignon" bezeichnet. Dabei treten die ersten klinischen Anzeichen etwa zwei bis drei Wochen nach Kastration auf. Der Samenstrang schwillt an, und es bilden sich Abszesse. Betroffene Pferde fallen mit Fieber, Skrotal- und Präputialödemen sowie lokaler Schmerzhaftigkeit auf. Im Falle von persistierenden Fremdkörperreaktionen, z.B. auf kontaminiertes resorbierbares Nahtmaterial, kann eine Erkrankung über einen langen Zeitraum, unter Umständen mehrere Jahre nach der Kastration, unerkannt bleiben. Diese Art der chronischen septischen Samenstrangentzündung ist klinisch durch eine größer werdende, nicht schmerzhafte Schwellung im Inguinal- und Skrotalbereich gekennzeichnet. Klinisch können Fistelöffnungen mit Absonderung von purulentem Exsudat (Samenstrangfistel) in Erscheinung treten; diese müssen aber nicht Teil des Krankheitsbildes sein. Der Name "Champignon" deutet auf das charakteristische pilzförmige Granulationsgewebe hin, das bei länger bestehenden Samenstrangfisteln vorkommen kann und ein unspezifisches morphologisches Phänomen darstellt. Wenn eine chronische lokale Infektion des Samenstrangstumpfes mit Staphylococcus aureus vorliegt, spricht man von einer Samenstrang-Botryomykose. Die Bezeichnung Botryomykose isł durch die ursprünglich irrtümlicherweise angenommene Beteiligung von Pilzen (Endung "-mykose") am Krankheitsgeschehen und das typische traubenartige Erscheinungsbild der bei diesem Krankheitsbild vorhandenen Mikrogranulome entstanden. Botryomykose kann grundsätzlich bei Mensch und Tier auftreten. Es sind sowohl kutane als auch viszerale Manifestationen bekannt. Zunächst beschrieb Bollinger im Jahre 1870 das Krankheitsbild bei einem Pferd mit einer granulomatösen Zubildung in der Lunge. Im späten 19. und frühen 20. Jahrhundert wurde dann Staphyloccocus aureus aus "Botryomykosen" isoliert. Im weiteren Verlauf konnte die bakterielle Genese der Erkrankung durch experimentelle Auslösung von Botryomykose bei Kaninchen durch Infektion mit Staphyloccocus aureus bewiesen werden. Die genaue Pathogenese der Erkrankung ist bis heute nicht vollständig geklärt, es gibt jedoch Hinweise darauf, dass sie durch das gleichzeitige Vorliegen von virulenten Staphylokokken und eines Fremdkörpers (z.B. Nahtmaterial) sowie einer Immunantwort des betroffenen Individuums im Sinne einer Fremdkörper-Reaktion entsteht. Durch die Gruppierung in Form von Bakterientrauben und die Bildung von rundlich bis stern- oder keulenförmig um die Bakterien angelagertem, eosinophilem Material, welches wahrscheinlich aus AntigenAntikörperkomplexen, Zelldebris, Glykoproteinen, Lipiden und Kalzium besteht (Splendore-Hoeppli-Phänomen), widerstehen die beteiligten Bakterien der Elimination durch die Entzündungsreaktion. Die hierdurch verhinderte Phagozytose und intrazelluäre Abtötung der Bakterien sowie schlechte Zugänglichkeit für Antibiotika werden als ursächlich für den chronischen Charakter dieser Erkrankung angesehen.

In dem hier beschriebenen Fall wurde ein acht Jahre alter Mecklenburger Schimmel-Wallach aufgrund einer diffusen, ödematösen Schwellung im Bereich des Präputiums und einer zunehmenden Störung des Gangbildes der Hinterhand an der Klinik für Pferde der Stiftung Tierärztliche Hochschule, Hannover vorgestellt. Vorberichtlich war das Pferd etwa fünf Jahre zuvor als Wallach erworben worden. Der Besitzerin lagen keine Informationen über den Zeitpunkt oder die Art der Kastration vor. Die Schwellung des Präputiums war der Besitzerin erst wenige Wochen zuvor aufgefallen.

Während der klinischen Allgemeinuntersuchung wurde kein besonderer Befund erhoben, und das kleine Blutbild war mit einem Hämatokrit von 33,7\%, einem Gesamteiweiß von 74 $\mathrm{g} / \mathrm{l}$ und einem Leukozytengehalt von 7,6 G/l unauffällig. Bei der speziellen klinischen Untersuchung stellte sich die Haut im Skrotalbereich intakt dar, und es fiel eine diffuse, oberflächlich teigartig-eindrückbare, in der Tiefe derbe Schwellung in der linken Inguinalregion am kaudalen Ende des Präputiums auf (Abb. 1). Eine transkutane ultrasonographische Untersuchung dieses Bereiches lieferte Hinweise auf ein Ödem der Unterhaut sowie auf eine rundliche, in Richtung des linken äußeren Leistenringes ziehende und in der Tiefe schlecht abgrenzbare Struktur mit einer hyperechogenen Kapsel und einem hypoechogenen Zentrum mit läppchenartigen hyperechogenen Arealen (Abb. 2). Weiterhin fiel ultrasonographisch eine leichte Aktivierung der Lymphonodi inguinales superficiales auf. Bei der transrektalen Palpation wurden keine besonderen Befunde im Bereich der inneren Leistenringe oder des kaudalen Abdomens erhoben. Die transrektale Sonographie lieferte Hinweise auf eine geringgradige Aktivie- 
rung der Lymphonodi iliaci mediales (Abb. 3). Das Pferd zeigte im Trab eine geringgradig undeutliche Lahmheit der linken Hintergliedmaße.

Als Differentialdiagnosen wurden zu diesem Zeitpunkt ein neoplastisches Geschehen oder eine chronische granulomatöse bzw. abszedierende Samenstrangentzündung in Betracht gezogen. Nach ausführlicher Aufklärung der Besitzerin über die Nutzen und Risiken wurden zur weiteren Charakterisierung der Umfangsvermehrung mehrere Feinnadelbioptate entnommen. Die pathohistologische Untersuchung der Bioptate ergab das Vorliegen von kollagenfaserreichem Bindegewebe und Fettgewebe mit mittelgradiger, multifokaler bis konfluierender lympho-histiozytärer und plasmazellulärer Entzündung und septierender Fibrose. Es war kein Lymphknotengewebe nachweisbar, und es gab keinen Hinweis auf eine bestehende Neoplasie. In Abstimmung mit der Besitzerin wurde die Entscheidung zur chirurgischen Entfernung der Zubildung in Narkose getroffen. Die Zubildung wurde en bloc über einen ca. $15 \mathrm{~cm}$ langen, kranio-kaudal verlaufenden, leicht S-förmigen Hautschnitt entfernt. Während der Operation wurden hoch dorsal Verwachsungen der Umfangsvermehrung mit dem Processus vaginalis und den Resten des Samenstranges erkennbar, so dass dieser nach Eröffnung des Scheidenhautfortsatzes und nach Ligatur des Processus pampiniformis, des Ductus deferens und der Arteria testicularis mittels quetschend-schneidender Kastrationszange bzw. elektrochirurgisch proximal der Umfangsvermehrung abgesetzt wurde. Der Processus vaginalis wurde separat mit einer Transfixationsligatur verschlossen und mittels Emaskulator entfernt. Die verbleibende Wunde wurde mit einem EndlosGazedrain, der über einen separaten, ca. $2 \mathrm{~cm}$ langen, weiter kranial gelegenen Schnitt ausgeführt wurde, tamponiert. Die verbleibende Wunde wurde in zwei Schichten verschlossen. Perioperativ und über die nachfolgenden Tage erhielt das Pferd $10 \mathrm{mg} / \mathrm{kg}$ Körpergewicht Amoxicillin-Natrium zweimal täglich i.v. (Belamox ${ }^{\circledR}$, bela-pharm $\mathrm{GmbH} \&$ Co. KG, Vechta, Germany) und $1,1 \mathrm{mg} / \mathrm{kg}$ Körpergewicht Flunixin-Meglumin zweimal täglich, zunächst i.v., später oral (Flunidol ${ }^{\circledR}$ RPS $50 \mathrm{mg} / \mathrm{ml}$ bzw. Flunidol ${ }^{\circledR} 5 \%$, CP-Pharma, Burgdorf, Germany). Der eingebrachte Endlos-Gazedrain wurde im Verlauf von 60 Stunden sukzessive gezogen.

Teile der Umfangsvermehrung wurden zur pathohistologischen und mikrobiologischen Untersuchung an das Institut für Pathologie bzw. an das Institut für Mikrobiologie der Stiftung Tierärztliche Hochschule, Hannover geschickt. Pathohistologisch wurden Anteile des Ductus deferens inmitten der Zubildung nachgewiesen. Im angrenzenden Fettgewebe lagen eine ausgeprägte pyogranulomatöse Entzündung mit kokkoi- den Bakterienkolonien und Splendore-Hoeppli-Material vor. Weiterhin wurden multifokal nekrotische Areale sowie eine ausgeprägte Granulationsgewebsbildung festgestellt (Abb. 4). Mikrobiologisch wurden große Mengen von Staphyloccocus aureus nachgewiesen. Unter Einbeziehung aller Befunde wurde die Diagnose einer chronischen granulomatösen Samenstrangentzündung unter Beteiligung von Staphyloccocus aureus (Botryomykose) gestellt.

Zur weiteren antimikrobiellen Behandlung erfolgte nach Prüfung der Sensibilität eine Umstellung auf Trimethoprim-Sulfadiazin in der Dosierung von $30 \mathrm{mg} / \mathrm{kg}$ Körpergewicht zweimal täglich oral (Synutrim ${ }^{\circledR} 72 \%$ Pulver, Vétoquinol $\mathrm{GmbH}$, Ravensburg, Germany), und das Pferd wurde sechs Tage nach der Operation mit gutem Allgemeinbefinden aus der Klinik für Pferde der Stiftung Tierärztliche Hochschule, Hannover entlassen. Die Antibiotikatherapie wurde für weitere drei Wochen fortgesetzt, und das Pferd wurde über vier Wochen bei Boxenruhe mit kontrolliertem Bewegungsprogramm gehalten. Bei der telefonischen Nachfrage zwei Wochen nach der Entlassung berichteten Besitzerin und Haustierarzt über einen guten Heilungsverlauf. Während eines Telefonats neun Monate nach der Operation teilte die Besitzerin mit, dass das Pferd wieder vollumfänglich reiterlich genutzt werde und weder eine Lahmheit noch eine äußerliche Auffälligkeit im Präputial- und Inguinalbereich feststellbar sei. Diese Befunde wurden bei einer eigenen Kontrolluntersuchung etwa ein Jahr nach der Operation bestätigt (Abb. 1).

Gangstörungen der Hinterhand werden als potentielle Folgen von Kastrationskomplikationen beschrieben. Im vorliegenden Fall wurde die Ursache für die Hinterhandlahmheit nicht mit Hilfe diagnostischer Betäubungen lokalisiert, so dass eine zusätzlich zur Samenstrang-Botryomykose bestehende orthopädische Erkrankung als Lahmheitsursache nicht ausgeschlossen werden konnte. Da der Grad der Gangstörung vorberichtlich jedoch mit dem Grad der Umfangsvermehrung in der Inguinalregion zugenommen hatte und die Lahmheit nach Entfernung des Samenstranggranulomes vollständig verschwand, wird in diesem Fall ein Kausalzusammenhang zwischen beiden Phänomenen angenommen. Dabei sind sowohl eine schmerzbedingte als auch eine mechanische Beeinträchtigung des Bewegungsablaufes durch die Umfangsvermehrung denkbar. Schlussfolgernd zeigt der vorliegende Fall, dass bei einer chronischen Samenstranginfektion mit Staphylococcus aureus nach Kastration (Botryomykose) die chirurgische Behandlung mit begleitender systemischer Gabe von Antibiotika ein erfolgreiches Therapiekonzept darstellt, das als Ansatz der ersten Wahl in Betracht gezogen werden sollte. 